\title{
In vitro Anticancer Activity of Aponogeton madagascariensis Anthocyanin Extracts
}

\author{
Arunika N. Gunawardena $\mathbb{D}^{1}$, PHD ${ }^{1, *}$, Alice Rollini, BSc ${ }^{1}$, Andrea N. Rasmussen, $\mathrm{MSc}^{2}$, \\ Adrian N. Dauphinee $\mathrm{PHD}^{1,2}$, Wasundara Fernando, $\mathrm{PHD}^{3}$, Shawna Mackinnon, $\mathrm{PHD}^{4}$, \\ A. Harrison Wright $\mathbb{D}, \mathrm{PHD}^{4}$, David W. Hoskin, $\mathrm{PHD}^{3}$ \\ ${ }^{1}$ Department of Biology, Faculty of Science, Dalhousie University, Halifax, NS, B3H 4R2, Canada \\ ${ }^{2}$ Department of Molecular Sciences, Swedish University of Agricultural Sciences, Uppsala, Uppsala County, 750 07, Sweden \\ ${ }^{3}$ Departments of Pathology, Microbiology and Immunology, and Surgery, Faculty of Medicine, Dalhousie University, Halifax, NS, \\ B3H 4R2, Canada \\ ${ }^{4}$ Agriculture and Agri-Food Canada, Kentville Research \& Development Centre, 32 Main St, Kentville, Nova Scotia, B4N 1J5, Canada \\ *0 Corresponding Author: Arunika.gunawardena@dal.ca
}

\begin{abstract}
INTRODUCTION: Aponogeton madagascariensis (lace plant) is a freshwater aquatic flowering plant belonging to the family Aponogetonaceae that forms leaf perforations via programmed cell death (PCD). The lace plant has emerged as a novel model system for studying PCD in planta due to the predictability and accessibility of this process. Anthocyanins, and the balance between ROS and antioxidants, play a central role in regulating PCD in lace plant leaves. Aponogetonaceae family members have shown medicinal properties, including antioxidant and anticancer activities; however, nothing is known about the lace plant's potential for medicinal use. Therefore, this study evaluated the anticancer activities of lace plant anthocyanin extracts.

METHODS: Cell line growth and viability were assessed following exposure to lace plant leaf anthocyanin extracts. This study utilized a triple-negative breast cancer cell line, MDA-MB-231, two human ovarian epithelial cancer cell lines, OVCAR-8 and SKOV-3, along with a normal mammary epithelial cell line, MCF-10A. Furthermore, crude anthocyanin extracts were fractionated into anthocyanin and non-anthocyanin containing fractions and tested only on MDA-MB-231 cells.

RESULTS AND DISCUSSION: The crude anthocyanin extracts from lace plant leaves inhibited the growth of MDA-MB-231, OVCAR-8, and SKOV-3 cells in a concentration-dependent manner and had no effect on MCF-10A cells. Lace plant crude anthocyanin extracts appeared to induce apoptosis in MDA-MB-231 cells. Interestingly, treatment with anthocyanin and non-anthocyanin fractions decreased the growth of MDA-MB-231, similarly to crude anthocyanin extracts, suggesting the presence of other anticancer compounds in the lace plant extracts.
\end{abstract}

CONCLUSIONS: Lace plant crude anthocyanin extracts and corresponding fractions have in vitro anticancer activities.

KEYWORDS: Apoptosis; crude extracts; cytotoxicity; lace plant; non-anthocyanin; programmed cell death

\section{Introduction}

The aquatic lace plant, Aponogeton madagascariensis (Mirbel) H. Bruggen, belongs to the family Aponogetonaceae, which consists of about 57 species, distributed mainly among the tropical and subtropical regions of the world [1]. Lace plant is endemic to the river systems of Madagascar [2] and its common name is representative of its distinct lattice-like leaf morphology (Figure $1 \mathrm{~A}, \mathrm{~B}$ ). This characteristic leaf pattern is due to perforations that form between longitudinal and transverse veins via programmed cell death (PCD). The leaves develop from an underground corm in a heteroblastic series in which the first 1-3 emerging leaves form without perforations, while subsequent leaves do form 

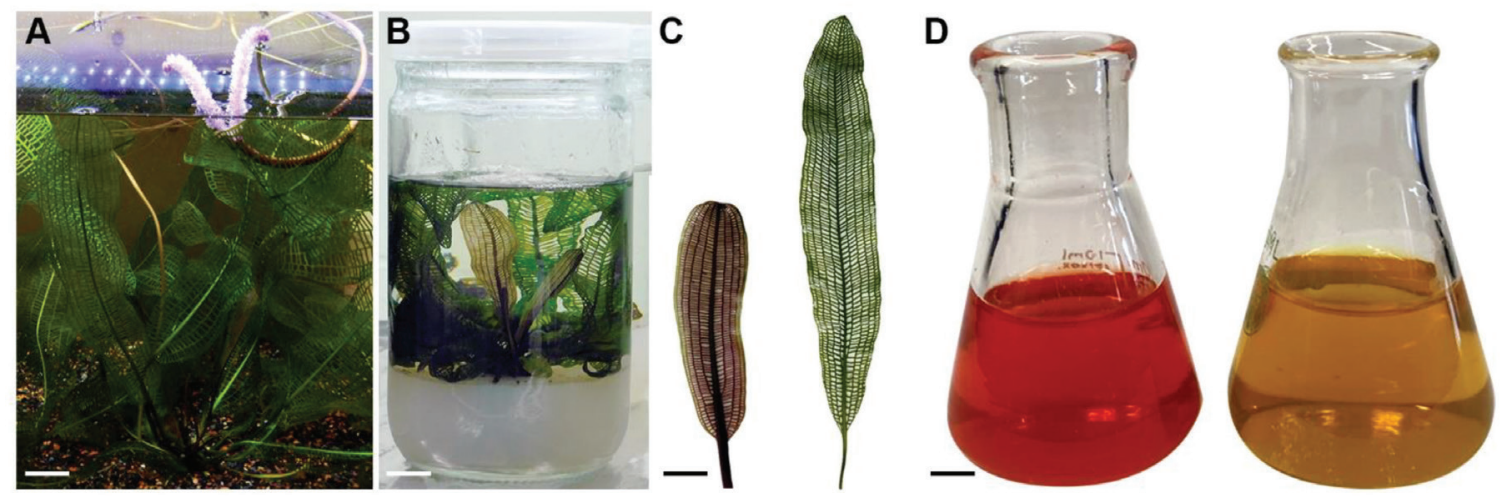

Figure 1. Lace plant (A. madagascariensis) is an aquatic monocot used as a model organism to study programmed cell death (PCD) in planta due to its unique leaf perforation pattern. (A) Lace plant in aquarium setting showing perforated adult leaves and purple inflorescence. (B) Sterile lace plant grown in a jar containing liquid and solid MS medium. (C) Window (left) stage leaf with a pink coloration due to anthocyanin, a water-soluble pigment, and mature (right) stage leaf with fully formed perforations and green coloration due to an abundance of chlorophyll. (D) Crude anthocyanin extracted from window (left) and mature (right) stage leaves. Scale bars:

$A=5 \mathrm{~cm}, \mathrm{~B}=2 \mathrm{~cm}, \mathrm{C}=1 \mathrm{~cm}, \mathrm{D}=0.55 \mathrm{~cm}$

perforations. During the early stages of development, young leaves known as "window" stage leaves are pink in color due to the presence of anthocyanin pigments. This pigmentation disappears as leaves mature and chlorophyll pigmentation becomes more prominent (Figure 1C). The lace plant is an excellent model system for studying developmentally regulated PCD in planta due to the accessibility and predictability of perforation formation, the suitability of its thin and semi-transparent leaves for live cell imaging, and the established sterile culture system for propagation [3-10].

Family members such as $A$. distachyos, A. elongates, A. crispus, A. madagascariensis, and A. natans all have edible tubers and inflorescences, and have also been used for their medicinal properties [11-14]. For example, A. natans has antidiabetic activities [15] and A. undulates has antioxidant [16] as well as antitumor activities against cancers like Ehrlich ascites carcinoma (murine mammary adenocarcinoma; [17]). Aponogeton crispus and A. natans (commonly known as kekatiya) are used in Ayurvedic medicine to treat burning sensations, wounds, heart disease, excessive thirst and nausea $[16,18]$. Aponogeton undulates extracts are effective against ailments such as coughs, tuberculosis, acne, cancer, diarrhea and jaundice [16].

It is likely that other species in the Aponogetonaceae family have medicinal properties that have not yet been exploited. We are particularly interested in studying A. madagascariensis as it has provided novel insights into developmentally regulated PCD, as well as the important role played by antioxidants and anthocyanins during lace plant leaf development $[5,19]$. Anthocyanins are the most common and abundant flavonoid components present in the vacuoles of plant cells [20]. There are over
500 anthocyanin species across the plant kingdom, and they have nutritional values as well as medicinal properties such as antidiabetic, anticancer, anti-inflammatory, antimicrobial effects, and the capacity to prevent cardiovascular diseases [21-23]. Purified anthocyanins from various plant species have been extensively studied for their anticancer properties, using in vitro or in vivo models [24-26]; meanwhile the effectiveness of crude anthocyanin extracts is yet to be studied extensively. Favaro et al. [27] recently showed that crude anthocyanin extract from the fruits of Jussara (Euterpe edulis Martius) is suitable for both food and pharmaceutical applications. Moreover, crude anthocyanin extracts are often used in Ayurvedic medicine. This study investigated the effects of crude anthocyanin extracts from window and mature stage leaves on breast and ovarian cancer cells. Fractionation of the crude anthocyanin extracts allowed for the evaluation of the effects of anthocyanin and non-anthocyanin fractions on breast cancer cells in vitro. To the best of our knowledge, this is the first paper to report the in vitro cytotoxic effects of lace plant anthocyanin extracts on breast and ovarian cancer cells.

\section{Methods}

\section{Establishment of Lace Plant Cultures}

Lace plant corms were purchased from The PlantGuy (Alberta, Canada) and planted in a freshwater filtered aquarium. The aquarium had a Seachem Flourite substrate (Georgia, USA) and the plants were grown under a $12 \mathrm{~h}$ light/dark cycle using a Fluval Fresh \& Plant 2.0 LED bar (Rolf C. Hagen Inc., Québec, Canada). Each week, $15 \%$ of the water volume was changed and 
supplemented with $1 \mathrm{mg} / \mathrm{L}$ monopotassium phosphate, $10 \mathrm{mg} / \mathrm{L}$ potassium nitrate and $3 \mathrm{mg} / \mathrm{L} \mathrm{CSM+B}$ plantex (Aquarium Fertilizers, California, USA). Mature inflorescences (Figure 1A) were self-crossed with a cotton swab. Germinated seedlings were collected in water with a mesh and rinsed thoroughly with distilled water. The seedlings were surface sterilised for $5 \mathrm{~min}$ in $50 \%$ ethanol and then soaked in $20 \%$ bleach for $5 \mathrm{~min}$. The seedlings were then rinsed 3 times in distilled water, for 5 mins and then transferred to Murashige and Skoog (MS) medium and maintained via tissue culturing as described below.

\section{Lace Plant Tissue Culture}

Lace plant cultures were maintained and propagated according to Gunawardena et al. [9]. The plants were grown in $963 \mathrm{~mL}$ wide-mouth glass culture vessels (PhytoTechnology Laboratories, Kansas, USA) with approximately $450 \mathrm{~mL}$ of liquid MS medium (30 g/L sucrose, $2.15 \mathrm{~g} / \mathrm{L}$ MS basal salts, $100 \mathrm{mg} / \mathrm{L}$ myoinositol and $0.4 \mathrm{mg} / \mathrm{L}$ thiamine, $\mathrm{pH} 5.7$ ) and embedded in $200 \mathrm{~mL}$ of solid MS medium containing $1.25 \%$ agar (PhytoTechnology Laboratories, Kansas, USA, Figure 1B). Cultures were maintained at $24^{\circ} \mathrm{C}$ under fluorescent lighting (Philips Daylight Deluxe) at approximately $125 \mu \mathrm{mol} \mathrm{m}^{-2} \mathrm{~s}^{-1}$ on a $12 \mathrm{~h}$ light/dark cycle.

\section{Preparation of Crude Anthocyanin Extracts}

Anthocyanin extractions were performed using a protocol adapted from Dauphinee et al. [19]. Lace plant window or mature stage leaves (Figure 1C) were excised from axenic cultures, blot-dried, weighed and then flash frozen with liquid nitrogen. The leaves were then macerated into a fine powder with mortar and pestle. A formic acid/methanol (5/95, v/v) extraction buffer was added $(10 \mathrm{~mL} / \mathrm{g}$ tissue $)$ to the mixture that was then incubated in the dark on ice for $50 \mathrm{~min}$, filtered using an $80 \mu \mathrm{M}$ mesh and centrifuged at $10,000 \times \mathrm{g}$ for $10 \mathrm{~min}$. The supernatant was filtered again (Figure 1D) using the same mesh onto glass culturing plates to allow the extraction buffer to evaporate, in the absence of light, overnight at $25^{\circ} \mathrm{C}$. The dry residue was collected using a sterile razor and stored at $-20^{\circ} \mathrm{C}$ until needed. Prior to application, the residue was dissolved in dimethyl sulfoxide (DMSO) to generate a stock solution of $100 \mathrm{mg} / \mathrm{mL}$.

\section{Fractionation of Lace Plant Crude Anthocyanin Extract}

Lace plant crude anthocyanin extract (10-30 mg) was suspended in $1 \mathrm{~mL}$ of formic acid/water $(5 / 95, \mathrm{v} / \mathrm{v})$ and applied onto a 1 g C18 SPE cartridge (Waters Corp., Mississauga, ON, Canada) that had been previously sequentially equilibrated with $10 \mathrm{~mL}$ of each of the following: methanol, formic acid/methanol (5/95, v/v), ethyl acetate, methanol/water $(15 / 85, \mathrm{v} / \mathrm{v})$, formic acid/ water $(5 / 95, v / v)$ and finally water. Separate sample eluates were collected when the cartridge was eluted with $10 \mathrm{~mL}$ of formic acid/water $(5 / 95, \mathrm{v} / \mathrm{v})$, and $10 \mathrm{~mL}$ of methanol/water $(15 / 85, \mathrm{v} / \mathrm{v})$. The cartridge was dried under vacuum and then a fraction was collected by eluting the cartridge with $10 \mathrm{~mL}$ of ethyl acetate. The cartridge was dried again, and a fraction was collected by eluting the cartridge with $10 \mathrm{~mL}$ of formic acid/ methanol $(5 / 95, v / v)$. The anthocyanin-containing fraction was prepared by removing the organic solvent from the formic acid/water $(5 / 95, \mathrm{v} / \mathrm{v})$ fraction using a stream of nitrogen. Fractions obtained from methanol/water $(15 / 85, v / v)$, ethyl acetate and water elution were combined and placed under a stream of nitrogen to remove the organic solvents. The remaining aqueous solution was freeze-dried to yield a non-anthocyanin-containing fraction.

\section{Cell Culture Conditions}

MDA-MB-231 triple-negative breast cancer (TNBC) cells were provided by Dr. S. Drover (Memorial University of Newfoundland, St. John's, NL, Canada) and authenticated by short tandem repeat analysis conducted by ATCC (Manassas, VA, USA). OVCAR- 8 and SKOV-3 human epithelial ovarian cancer cells were obtained from and authenticated by ATCC. MCF-10A immortalized human mammary epithelial cells used as a control in this study were obtained from Dr. P. Marcato (Dalhousie University, Halifax, NS, Canada). All cancer cells were cultured using Dulbecco's Modified Eagle's Medium (DMEM) supplemented with $10 \% \mathrm{v} / \mathrm{v}$ heatinactivated fetal bovine serum (FBS), $100 \mathrm{U} / \mathrm{mL}$ penicillin, $100 \mu \mathrm{g} / \mathrm{mL}$ streptomycin, $5 \mathrm{mM} \mathrm{N}$-2 hydroxyethylpiperazine- $\mathrm{N}^{\prime}$-2-ethanesulfonic acid (HEPES) buffer ( $\mathrm{pH} 7.4$ ), and $2 \mathrm{mM} \mathrm{L}$-glutamine, and maintained at $37^{\circ} \mathrm{C}$ in a humidified $10 \% \mathrm{CO}_{2}$ incubator. Cells were passaged upon reaching $70-80 \%$ confluency, using $0.25 \%$ trypsinethylenediamine tetraacetic acid (EDTA). The control cell line, MCF-10A, was cultured in F12/DMEM (1:1) supplemented with $10 \%$ horse serum, $0.02 \mu \mathrm{g} / \mathrm{mL}$ epidermal growth factor, $0.5 \mu \mathrm{g} / \mathrm{mL}$ hydrocortisone, $10 \mu \mathrm{g} / \mathrm{mL}$ bovine insulin, $100 \mu \mathrm{g} / \mathrm{mL}$ penicillin and $100 \mu \mathrm{g} / \mathrm{mL}$ streptomycin and maintained in a $5 \%$ humidified $\mathrm{CO}_{2}$ incubator. MCF-10A cells were also passaged upon reaching $70-80 \%$ confluency using sterile phosphatebuffered saline (PBS) followed by $0.25 \%$ trypsin-EDTA. 


\section{MTT (3-(4,5-Dimethylthizol-2-yl)-2,5- Diphenyltetrazolium Bromide) Assay for Cell Growth}

Cell growth was assessed using the 3-(4,5-dimethylthizol2-yl)-2,5-diphenyltetrazolium bromide (MTT) colorimetric assay [28]. The light sensitive MTT reagent was converted to insoluble purple formazan crystals by mitochondrial succinate dehydrogenases. MTT assays were performed with crude and fractions of anthocyanin extracts (anthocyanin or non-anthocyanin). Both window and mature crude anthocyanin extracts were tested on breast (MDA-MB-231) and ovarian (OVCAR-8 and SKOV-3) cancer cells, as well as on normal mammary epithelial cells (MCF-10A). Window and mature anthocyanin and non-anthocyanin fractions derived from the crude extracts were tested only on MDA-MB-231 and MCF-10A cells.

All cells were seeded at $5 \times 10^{3}$ cells/well in 96-well flat-bottom cell culture plates and incubated at $37^{\circ} \mathrm{C}$ overnight to induce cell adhesion. Adherent cells were treated with 0 (vehicle control), 25, 50, 100 or $250 \mu \mathrm{g} / \mathrm{mL}$ concentrations of either window or mature stage lace plant leaf extract, and cultured for 24,48 or $72 \mathrm{~h}$. At the end of culture, $10 \mu \mathrm{L}$ MTT was added to each well, the plates were incubated for $2-3 \mathrm{~h}$, and then centrifuged (Baxter centrifuge, Hallandale Beach, FL, USA) at $1400 \times \mathrm{g}$ for $5 \mathrm{~min}$. The supernatant was discarded, and formazan crystals were dissolved in $0.1 \mathrm{~mL}$ DMSO. Changes in optical density were determined at $570 \mathrm{~nm}$ using an ASYS Expert 96 Microplate Reader (Biochrom, Admiral Place, Guelph, ON, Canada). Cell metabolic activity as a measure of cell growth was expressed as a percentage compared to the medium control. Each experiment was repeated at least three times.

\section{Crystal Violet Staining for Cell Morphology Analysis}

Cells were plated in 6-well flat-bottom cell culture plates at $1 \times 10^{5} \mathrm{cells} /$ well and left for $24 \mathrm{~h}$, while cultures at $5 \times 10^{4}$ cells/well were left for 48 or $72 \mathrm{~h}$. However, only $48 \mathrm{~h}$ results were shown in the results section. Cells were left to adhere overnight at $37^{\circ} \mathrm{C}$. Adherent cells were then treated with 0 (vehicle control), 50 or $100 \mu \mathrm{g} / \mathrm{mL}$ window or mature stage crude leaf extract. At the end of culture, plates were centrifuged at $1400 \times \mathrm{g}$ for $5 \mathrm{~min}$, after which, the medium was removed, and cells were washed with PBS. Cells were then fixed with $500 \mu \mathrm{L}$ methanol and incubated for $15 \mathrm{~min}$. After the incubation period, methanol was removed, and crystal violet dye was added $(1 \mathrm{~mL} /$ well $)$. The plates were covered with tin foil and placed on a rocker at maximum speed for $5 \mathrm{~min}$. Finally, the cells were rinsed with water to eliminate excess dye and left to air-dry.
Stained cell cultures were scanned using a Nikon Eclipse $\mathrm{Ti}$ microscope (Nikon, Mississauga, ON, Canada). Images were captured using NIS Elements software and a Nikon DS-Fil digital camera head (Nikon Instruments Canada). Each experiment was repeated three times.

\section{Oregon Green-488 Staining for Flow Cytometric Cell Proliferation Assay}

Twenty hours before starting the assay, MDA-MB-231, OVCAR-8 and SKOV-3 cancer cells were serum-starved to synchronize their cell cycle. Cells were seeded into 6-well flat-bottom cell culture plates at a density of $5 \times 10^{4}$ cells/well and allowed to adhere overnight. Adherent cells were washed with warm PBS, stained with $1.25 \mu \mathrm{M}$ Oregon Green 488 (Carboxy DFFDA-SE, Catalog number: C34555, Invitrogen) prepared in warm $\left(37^{\circ} \mathrm{C}\right)$ serum-free medium, and incubated for $45 \mathrm{~min}$ at $37^{\circ} \mathrm{C}$. Cells were then thoroughly washed with warm complete DMEM, and incubated for $2 \mathrm{~h}$ to induce cell recovery. Cells for the non-proliferative baseline control were then harvested, fixed in $1 \%$ paraformaldehyde (PFA) and stored at $4^{\circ} \mathrm{C}$ until use; they had the highest fluorescence at $\mathrm{t}=0 \mathrm{~h}$. The remaining cell cultures were treated with 0 (vehicle control), 25 or $50 \mu \mathrm{g} / \mathrm{mL}$ of the crude window or mature leaf extracts. Treated cells were incubated for $72 \mathrm{~h}$ in the dark before analysis by flow cytometry using a FACSCalibur instrument (BD Bioscience, Mississauga, ON, Canada). The number of cell divisions ( $\mathrm{n}$ ) was calculated as follows: $\mathrm{MF}$ control $=2^{\mathrm{n}} \times \mathrm{MF}_{\text {treatment }}$ using the mean fluorescence (MF) of the treatment (MF treatment $)$ and the MF of the non-proliferative control ( $\mathrm{MF}$ control $)$. The fluorescence of the non-proliferative control was used to normalize the MF of anthocyanin-treated cells. Each experiment was repeated three times.

\section{TdT-Mediated dUTP Nick End Labelling (TUNEL) Staining for DNA Fragmentation}

TUNEL staining, in which TdT-mediated dUTP nick ends are labelled [29], was used to characterise DNA fragmentation in breast cancer cells treated with window or mature leaf stage extracts. MDA-MB-231 cells were seeded in 6-well flat-bottom cell culture plates and incubated overnight at $37^{\circ} \mathrm{C}$ to support cell adhesion at a density of $1 \times 10^{5}$ cells/well. Adherent cells were treated with 0 (vehicle control), 50 or $100 \mu \mathrm{g} / \mathrm{mL}$ window or mature stage leaf extracts and cultured for 24 or $48 \mathrm{~h}$. At the end of culture period, cells were harvested and cytoprep slides were prepared. TUNEL staining was performed using an In Situ Cell Death Detection Kit, POD (Roche Applied Science, Laval, QC, Canada), according to the manufacturer's instructions. Stained 
cells were detected under brightfield illumination using an $\mathrm{EVOS}^{\circledast} \mathrm{FL}$ digital microscope (ThermoFisher Scientific, Canada). Dark-colored staining is indicative of DNA fragmentation/damage. Each experiment was repeated three times.

\section{Transmission Electron Microscopy (TEM)}

MDA-MB-231 breast cancer cells were plated in 6-well plates $\left(2 \times 10^{5}\right)$ and incubated overnight at $37^{\circ} \mathrm{C}$ to promote cell adhesion. Adherent cells were then treated with 0 (vehicle control) or $100 \mu \mathrm{g} / \mathrm{mL}$ window or mature stage extract for $48 \mathrm{~h}$. At the end of the culture period, plates were centrifuged at $1400 \times \mathrm{g}$ for $5 \mathrm{~min}$, the medium was removed, and cells were fixed for $2.5 \mathrm{~h}$ with $2.5 \%$ glutaraldehyde diluted with $0.1 \mathrm{M}$ sodium cacodylate buffer. Cells were then scraped from each well, put into separate $1.5 \mathrm{~mL}$ microcentrifuge tubes, thoroughly rinsed for $10 \mathrm{~min}$ with $0.1 \mathrm{M}$ sodium cacodylate buffer, fixed for $2 \mathrm{~h}$ with $1 \%$ osmium tetroxide and rinsed quickly with distilled water. Samples were placed in $0.25 \%$ uranyl acetate and kept at $4^{\circ} \mathrm{C}$ overnight. The next day, samples were dehydrated with a graduated series of acetone ( $50 \%$ acetone $1 \times 10 \mathrm{~min}, 70 \%$ acetone $2 \times 10 \mathrm{~min}, 95 \%$ acetone $2 \times 10 \mathrm{~min}$ and $100 \%$ acetone 1 $\times 10 \mathrm{~min}$ ), and then infiltrated with Epon Araldite Resin, first using a 3:1 ratio (3 parts dried 100\% acetone: 1-part resin for $3 \mathrm{~h}$ ), then 1:3 acetone to resin overnight, and finally $100 \%$ Epon Araldite Resin twice for $3 \mathrm{~h}$. Samples were embedded in 100\% Epon Araldite Resin which was allowed to harden for $48 \mathrm{~h}$ in an oven set to $60^{\circ} \mathrm{C}$. Thin sections of about $100 \mathrm{~nm}$ were cut using a ReichertJung Ultracut E Ultramicrotome with a $100 \mathrm{~nm}$ thick diamond knife, and placed on 300 mesh copper grids, which were stained using $2 \%$ aqueous uranyl acetate for $10 \mathrm{~min}$, rinsed twice for $5 \mathrm{~min}$ with distilled water, stained with lead citrate for $4 \mathrm{~min}$, followed by a quick rinse with distilled water and left to air dry. Samples were viewed using a JEOL JEM 1230 transmission electron microscope (JEOL Canada Inc., St-Hubert, QC, Canada) at $80 \mathrm{kV}$ and images were captured using a Hamamatsu ORCA-HR digital camera [Advanced Microscopy Techniques (AMT), Woburn, MA, USA].

\section{Statistical Analysis}

GraphPad Prism analysis software (GraphPad Software, Inc.) was used for one-way analysis of variance (ANOVA) with the Tukey post-test to determine which pairwise comparisons are significant. Results were expressed as mean \pm SEM of three independent experiments.

\section{Image Preparation}

Bar graphs were created using GraphPad Prism 8 (GraphPad Software). Figures were prepared using
Adobe Photoshop and Illustrator CC (Adobe Systems Inc.). To improve image quality for lace plant leaves, backgrounds were removed. Adjustments to brightness and contrast were made evenly within images.

\section{Results}

\section{Crude Lace Plant Anthocyanin Extracts Inhibited the Metabolic Activity of Breast and Ovarian Cancer Cells}

The colorimetric MTT assay was used to assess the growth, as reflected by metabolic activity of TNBC MDA-MB-231 cells, human ovarian epithelial cancer OVCAR-8 and SKOV-3 cells, and immortalized human mammary epithelial MCF-10A cells when treated with crude anthocyanin-rich extracts from window and mature stage leaves of $A$. madagascariensis.

The MTT assay results after $48 \mathrm{~h}$ showed that crude window and mature anthocyanin extracts inhibit the metabolic activity, and therefore the growth of triplenegative breast and human epithelial ovarian cancer cells in a concentration-dependent manner $(\mathrm{P}<0.05$; Figure 2A). OVCAR-8 ovarian cancer cells showed a significant decrease in metabolic activity even with the lowest concentrations (i.e., $25 \mu \mathrm{g} / \mathrm{mL}$ ), of both window and mature anthocyanin leaf extracts, whereas SKOV-3 showed decreased metabolic activity at $25 \mu \mathrm{g} / \mathrm{mL}$ only with window anthocyanin extract and MDA-MB-231 solely with mature anthocyanin extracts (Figure 2A). Immortalized human mammary epithelial MCF-10A cells did not show any significant change in metabolic activity at any concentration of either window or mature anthocyanin crude extracts $(\mathrm{P}>0.05$; Figure 2A). Results from the MTT assays comparing breast and ovarian cancer cells to normal mammary cells showed that crude anthocyanin extracts from the window stage leaves of the lace plant significantly inhibited the metabolic activity of MDA-MB-231, OVCAR-8, and SKOV-3 at all four concentrations, compared to MCF$10 \mathrm{~A}$ cells (Figure 2B). Mature anthocyanin-rich extracts also significantly inhibited the metabolic activity of OVCAR-8 and SKOV-3 at all four concentrations compared to MCF-10A cells (Figure 2B), but the metabolic activity between MDA-MB-231 and MCF-10A was significant only at $100 \mu \mathrm{g} / \mathrm{mL}$ (Figure 2B). Comparisons of window and mature extracts for each cell line and dose showed no significant differences, except for MCF-10A cells at $250 \mu \mathrm{g} / \mathrm{mL}$ ( $\mathrm{P}>0.05$; Figure $2 \mathrm{C}$ ). Overall, MTT assay results indicated that the growth of human breast (MDA-MB-231) and ovarian (OVCAR-8 and SKOV-3) cancer cells were inhibited by crude anthocyanin extracts from the window and mature leaves of the lace plant in a concentration-dependent fashion. 


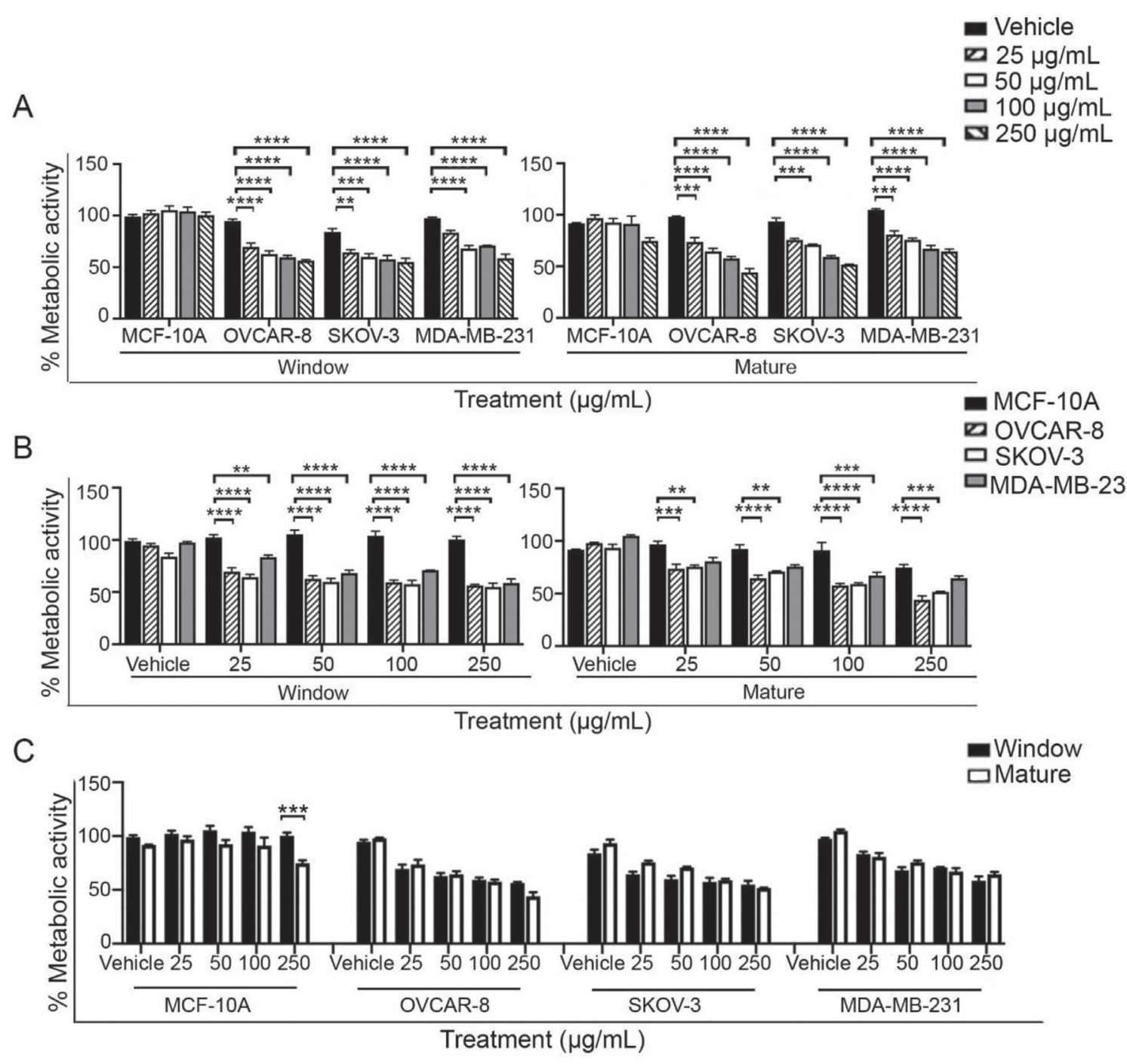

Figure 2. Crude A. madagascariensis anthocyanin extracts from window and mature stage leaves selectively inhibited the metabolic activity of triple-negative breast cancer cells (MDA-MB-231) and human epithelial ovarian cancer cells (OVCAR-8 and SKOV-3), but not in immortalized human mammary epithelial cells (MCF-10A). The \% metabolic activity of malignant and non-malignant cells treated with window and mature stage leaf crude extracts of A. madagascariensis was determined using a MTT assay after 48 h. (A) Cells treated with 25, 50, 100, $250 \mu \mathrm{g} / \mathrm{mL}$ showed that window and mature anthocyanin extracts decreased the metabolic activity of human cancer cells in a concentration-dependent manner. (B) The metabolic activity of breast cancer cells MDA-MB-231, and ovarian cancer cells OVCAR-8 and SKOV-3, treated with 25, 50, 100, $250 \mu \mathrm{g} / \mathrm{mL}$ of window and mature anthocyanin crude extracts was compared to the metabolic activity of normal mammary cells MCF-10A. (C) The $\%$ metabolic activity of MCF-10A, OVCAR-8, SKOV-3 and MDA-MB-231 cells treated with window anthocyanin extracts was compared to the metabolic activity of the same cells treated with mature anthocyanin extracts. Absorbance was measured at $570 \mathrm{~nm}$ and \% metabolic activity expressed as means \pm SEM of three independent experiments. Differences among means were analysed using a 1 -way ANOVA and Tukey's test; *P $<0.05$, $\star \star P P<0.01, * \star * P<0.001, * * \star * P<0.0001$.

\section{Crude Lace Plant Anthocyanin Extracts Decreased Cell Number and Induced Apoptotic-Like Morphological Changes on Breast and Ovarian Cancer cells}

Crystal Violet staining was used to detect morphological changes induced by the crude anthocyanin extracts from window and mature stage leaves of the lace plant on breast (MDA-MB-231), and ovarian (OVCAR-8 and
SKOV-3) cancer cells, as well as on normal mammary epithelial cells (MCF-10A).

Crude anthocyanin window and mature stage leaf extracts had a visible effect on the number and morphology of cancer cells that was not seen with noncancerous MCF-10A cells. No differences were observed between vehicle control and anthocyanin extracttreated MCF-10A cells; they were all homogeneously 


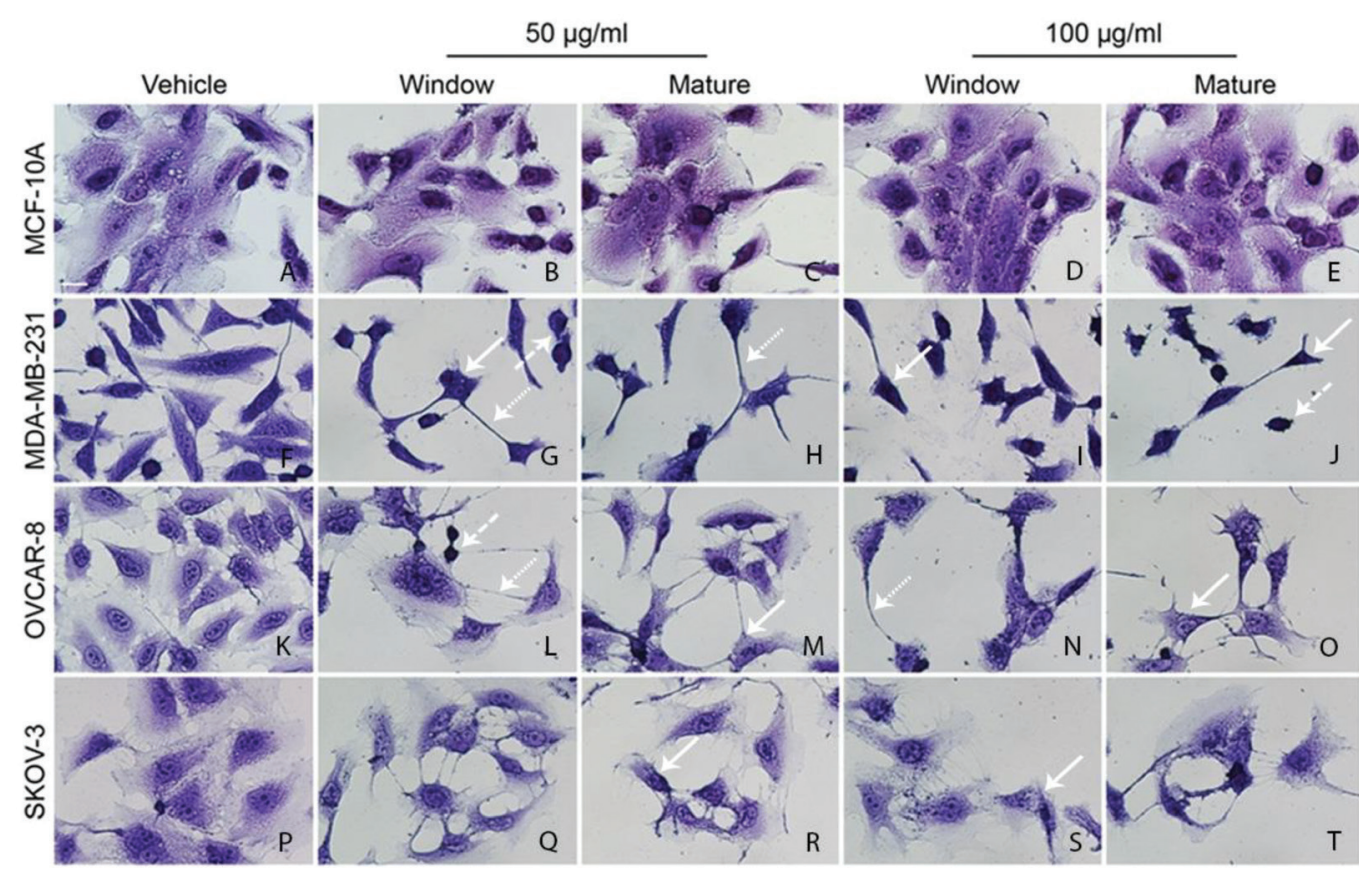

Figure 3. Crude A. madagascariensis anthocyanin extracts from window and mature stage leaves induced morphological changes in triple negative breast cancer cells (MDA-MB-231) and in human epithelial ovarian cancer cells (OVCAR-8 and SKOV-3), but not in immortalized human mammary epithelial cells (MCF-10A). MCF-10A cells (A-E), MDA-MB-231 (F-J), OVCAR-8 (K-O) \& SKOV-3 cells (P-T) were stained with Crystal Violet after $48 \mathrm{~h}$ of treatment with vehicle control, 50 or $100 \mu \mathrm{g} / \mathrm{mL}$ anthocyanin extracts. MCF-10A control (A) and cells treated with window and mature stage anthocyanin extracts at $50 \mu \mathrm{g} / \mathrm{mL}$ (B and C), and at $100 \mu \mathrm{g} / \mathrm{mL}$ (D and E) showed homogenously distributed cells. Vehicle controls of cancer cells (F, K and P) showed homogenously distributed cells; however, treated cancer cells (G-J; L-O; Q-T) showed apoptotic-like morphological characteristics compared to such as condensed cytoplasm (straight arrows), increased filopodia-like structures (dotted arrows), and a reduced number of cells and dead cells (dashed arrow). Scale bar $=10 \mu \mathrm{m}$

distributed and had a typical cytoplasm morphology (Figure $3 \mathrm{~A}-\mathrm{E}$ ). In contrast, for each cancer cell line, morphological differences were observed between cells treated with vehicle control and the ones treated with crude anthocyanin extracts. MDA-MB-231 cells treated with either 50 or $100 \mu \mathrm{g} / \mathrm{mL}$ extracts of window and mature stage leaves had shrunken cytoplasms (Figure $3 \mathrm{G}-\mathrm{J}$ ) and nuclei compared to their corresponding vehicle control cells (Figure 3F). Anthocyanin-treated OVCAR-8 and SKOV-3 cancer cells showed condensed and stretched cytoplasm with multiple filopodia-like structures reaching outwards to bridge with other neighboring cells (Figure 3 L-O, Q-T). Moreover, MDA-MB-231, OVCAR-8 and SKOV-3 cancer cells treated with either window or mature crude anthocyanin extracts showed a dramatic decrease in cell number (Figure $3 \mathrm{G}-\mathrm{J}, \mathrm{L}-\mathrm{O}, \mathrm{Q}-\mathrm{T}$ ) compared to their corresponding vehicle controls. Overall, the treatment of crude anthocyanin-rich extracts from window and mature stage leaves of $A$. madagascariensis led to apoptotic-like morphological characteristics and a decrease in the number of cells for breast
(MDA-MB-231) and ovarian (OVCAR-8 and SKOV-3) cancer cells only.

\section{Crude Lace Plant Anthocyanin Extracts Caused DNA Fragmentation in Breast Cancer Cells}

A TUNEL assay was used to determine whether exposure of breast cancer cells MDA-MB-231 to the crude A. madagascariensis anthocyanin leaf extracts caused DNA fragmentation, which is a hallmark of apoptosis [30]. MDA-MB-231 cells were cultured in the absence or presence of window or mature A. madagascariensis leaf extracts; 50 and $100 \mu \mathrm{g} / \mathrm{mL}$ were shown to be the lowest concentrations causing significant cell death as compared to the vehicle controls for both leaf extracts (Figure 4). At the $24 \mathrm{~h}$ time point, the breast cancer cells were still intact and started to show evidence of DNA fragmentation occurring in a concentrationdependent manner. After reaching $48 \mathrm{~h}$ of treatment with either window or mature anthocyanin extracts, most MDA-MB-231 cells were disrupted and showed additional evidence of DNA fragmentation (Figure 4; brown and black spots indicated by red arrows) also in a concentration-dependent manner. The results of the 
A
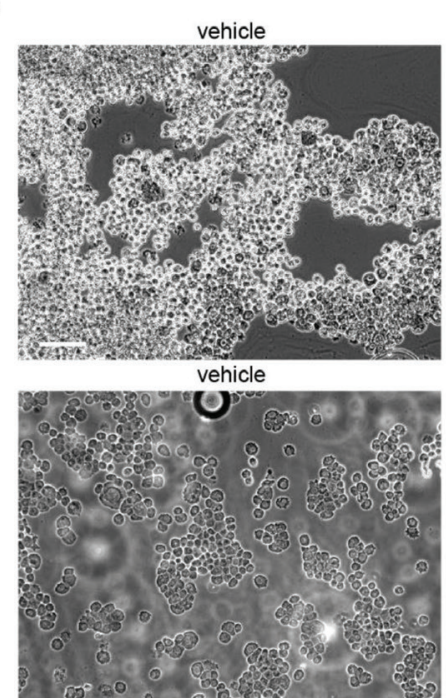

B
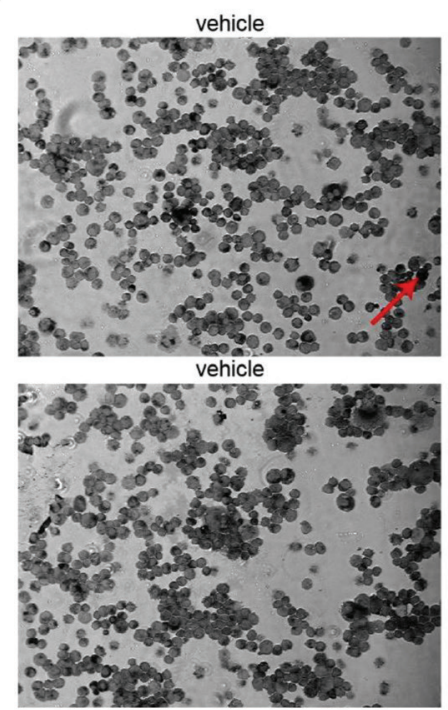

24 hours

window $50 \mu \mathrm{g} / \mathrm{ml}$

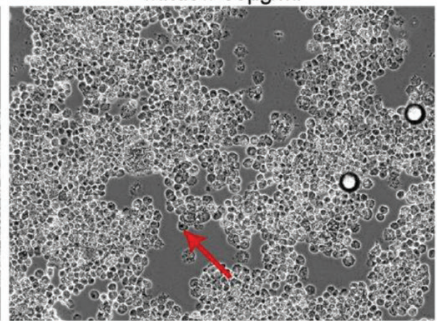

mature $50 \mu \mathrm{g} / \mathrm{ml}$

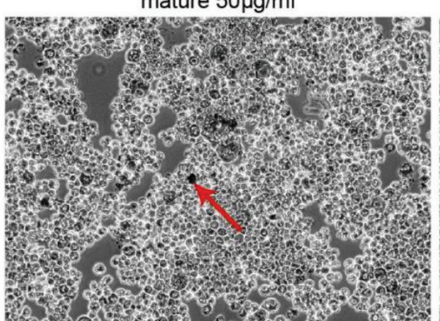

48 hours

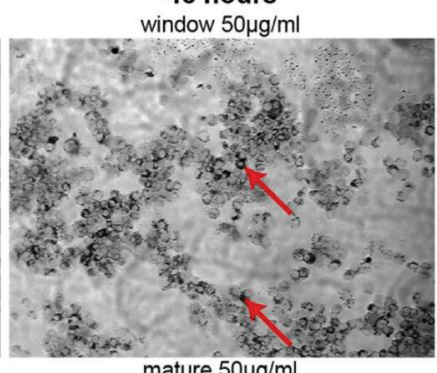

mature $50 \mu \mathrm{g} / \mathrm{ml}$

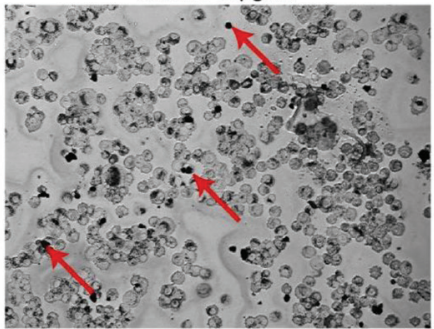

window $100 \mathrm{ug} / \mathrm{ml}$
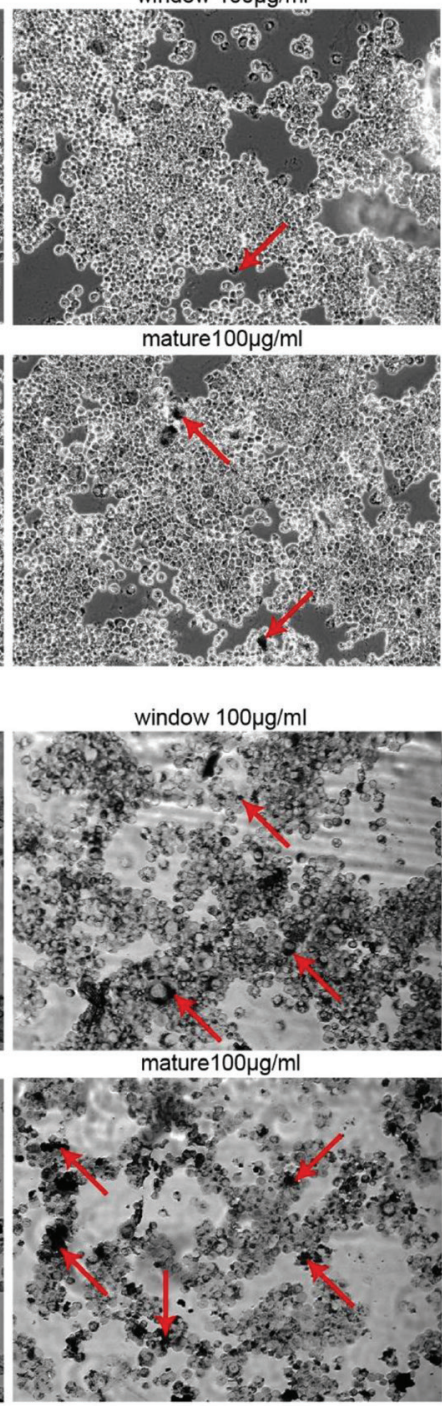

Figure 4. Crude anthocyanin extracts from window and mature stage leaves of A. madagascariensis induced DNA fragmentation on breast cancer cells. DNA fragmentation was measured with POD converter on MDA-MB-231 cells treated for $24 \mathrm{~h}(\mathrm{~A})$ and $48 \mathrm{~h}$ (B) with crude anthocyanin extracts from window and mature stage lace plant leaves at 50 and $100 \mu \mathrm{g} / \mathrm{mL}$ concentration. The assay was conducted as per kit instructions and imaged under brightfield on an EVOS digital microscope. DNA fragmentation is visible as dark-colored staining (red arrows). Scale bar $=100 \mu \mathrm{m}$.

TUNEL assays showed that both window and mature A. madagascariensis extracts caused DNA fragmentation and damage indicative of apoptosis in MDA-MB-231 triple-negative breast cancer cells.

\section{Crude Anthocyanin Lace Plant Extracts Caused Cell Ultrastructure Morphology Characteristic of Apoptotic Cells}

TEM was used to observe alterations in the ultrastructure of MDA-MB-231 cells treated with lace plant anthocyaninrich extracts from window and mature stage leaves (Figure 5). Cells treated with $100 \mu \mathrm{g} / \mathrm{mL}$ of either extract for $48 \mathrm{~h}$ exhibited condensed cell morphology, swollen mitochondria (Figure $5 \mathrm{E}$ ), nuclear membrane invagination, plasma membrane (PM) blebbing (Figure $5 \mathrm{~F}$ ) and the presence of apoptotic bodies (Figure $5 \mathrm{D}-\mathrm{I}$ ). In contrast, untreated control group cells did not have condensed cytoplasm, had typical mitochondria and no signs of nuclear membrane invagination, PM blebbing or apoptotic bodies (Figure $5 \mathrm{~A}-\mathrm{C}$ ).

\section{Crude Lace Plant Anthocyanin Extracts did not Show Significant Anti-Proliferative Activities in Ovarian and Breast Cancer Cells}

The anti-proliferative activity of crude anthocyanin extracts from window and mature stage leaves of the 

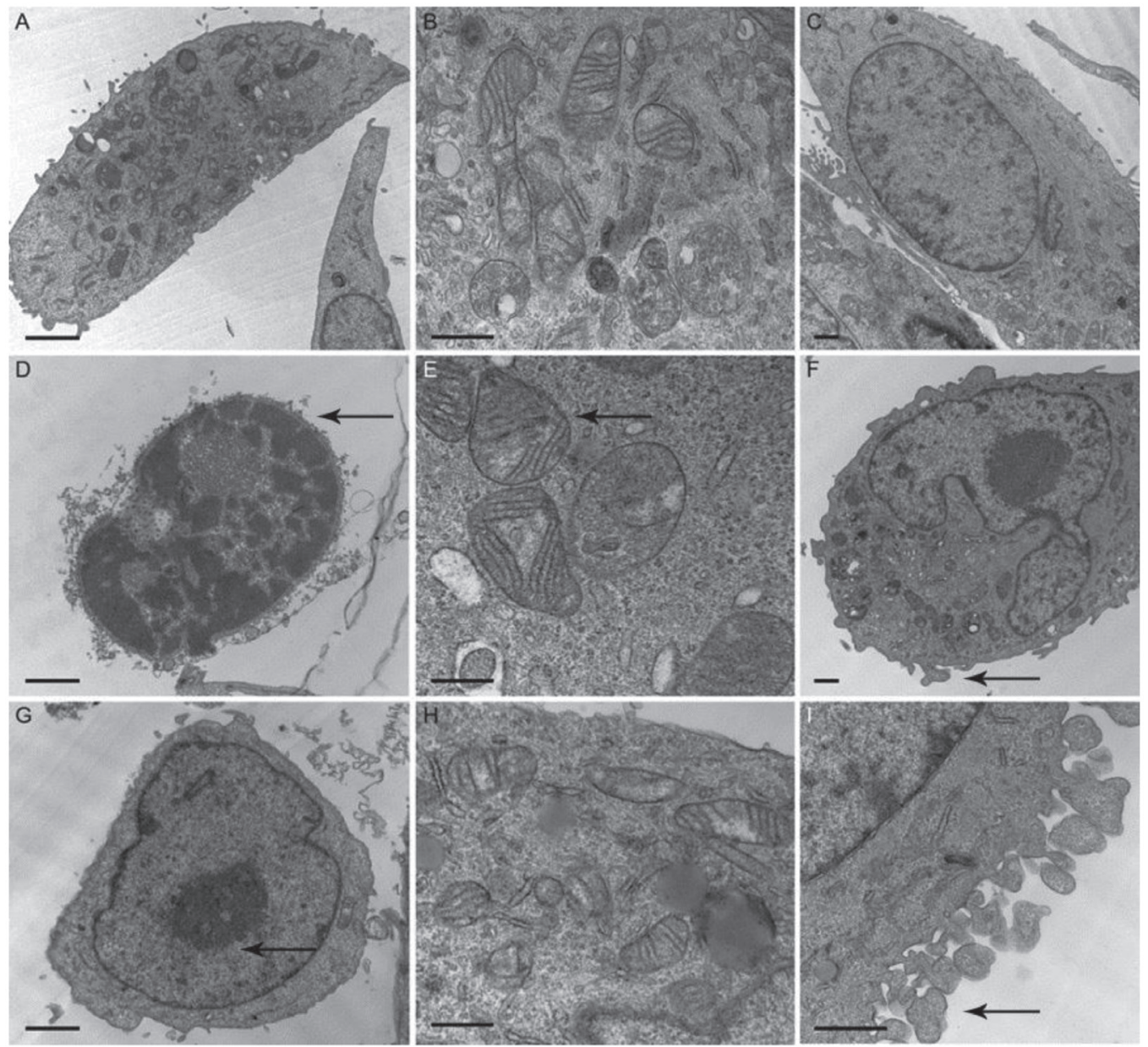

Figure 5. Crude anthocyanin from window and mature stage leaves of $A$. madagascariensis led to morphological changes of the ultrastructure of breast cancer cells. TEM of MDA-MB-231 cells $48 \mathrm{~h}$ after treatment including: vehicle control $(A-C), 100 \mu g / m L$ window stage $(D-F)$ and $100 \mu \mathrm{g} / \mathrm{mL}$ mature anthocyanin extract (G-I). Both window and mature anthocyanin extract treated cells demonstrated condensed cytoplasm ( $D$ arrow), condensed chromatin ( $\mathrm{G}$ arrow), swollen mitochondria (E arrow), membrane blebbing ( $F$ arrow) and apoptotic bodies (I arrow). Scale bars: A, D, G = $2 \mu \mathrm{m}, \mathrm{B}, \mathrm{E}, \mathrm{H}=500 \mathrm{~nm}, \mathrm{C}, \mathrm{F}, \mathrm{I}=1 \mu \mathrm{m}$.

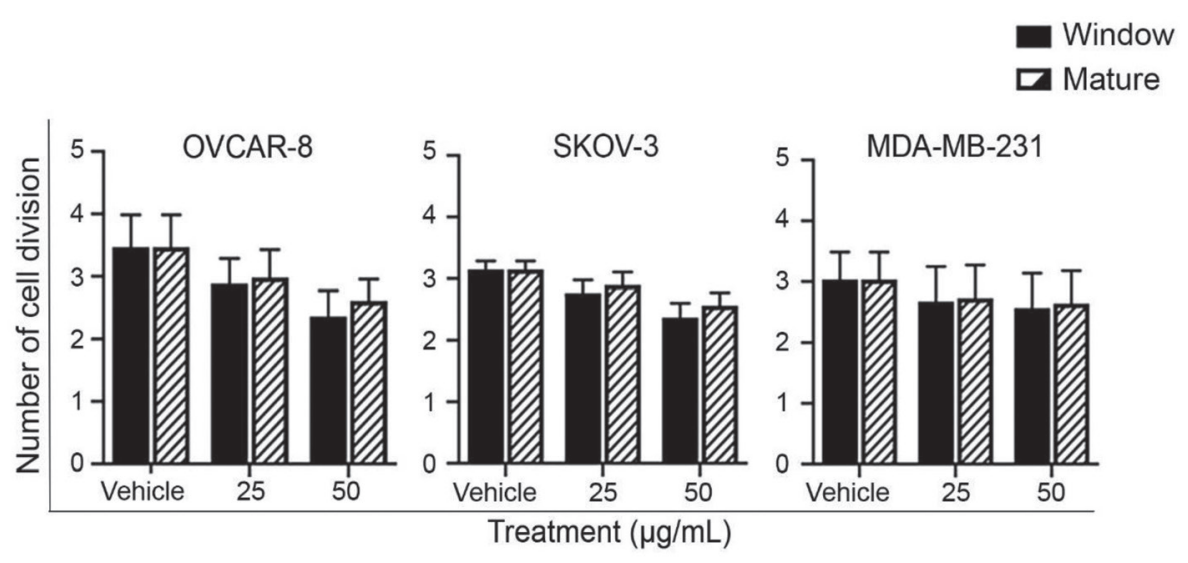

Figure 6. Crude anthocyanin extracts from A. madagascariensis did not have anti-proliferation effects on human ovarian and breast cancer cells. Synchronized with serum-free medium, ovarian cancer cells (OVCAR-8 and SKOV-3) and breast cancer cells (MDA-MB-231) were stained with Oregon Green-488, treated with 0, 25 or $50 \mathrm{\mu g} / \mathrm{mL}$ crude window or mature anthocyanin extracts and cultured for $72 \mathrm{~h}$. The cells were harvested and analysed by flow cytometry. The number of cell divisions was analysed via a one-way ANOVA and expressed as mean \pm SEM of three independent experiments. 
lace plant was measured using a collagen-binding fluorescent dye, Oregon Green-488. Flow cytometric analysis of Oregon Green 488-stained MDA-MB-231, OVCAR-8, and SKOV-3 cells treated with a subcytotoxic dose of crude window or mature anthocyanin extract $(25$ and $50 \mu \mathrm{g} / \mathrm{mL}$ ) revealed a gradual decrease in the number of cell divisions in a concentrationdependent fashion in all three cancer cell lines compared to their corresponding vehicle-treated cells (Figure 6). However, no significant difference was found between
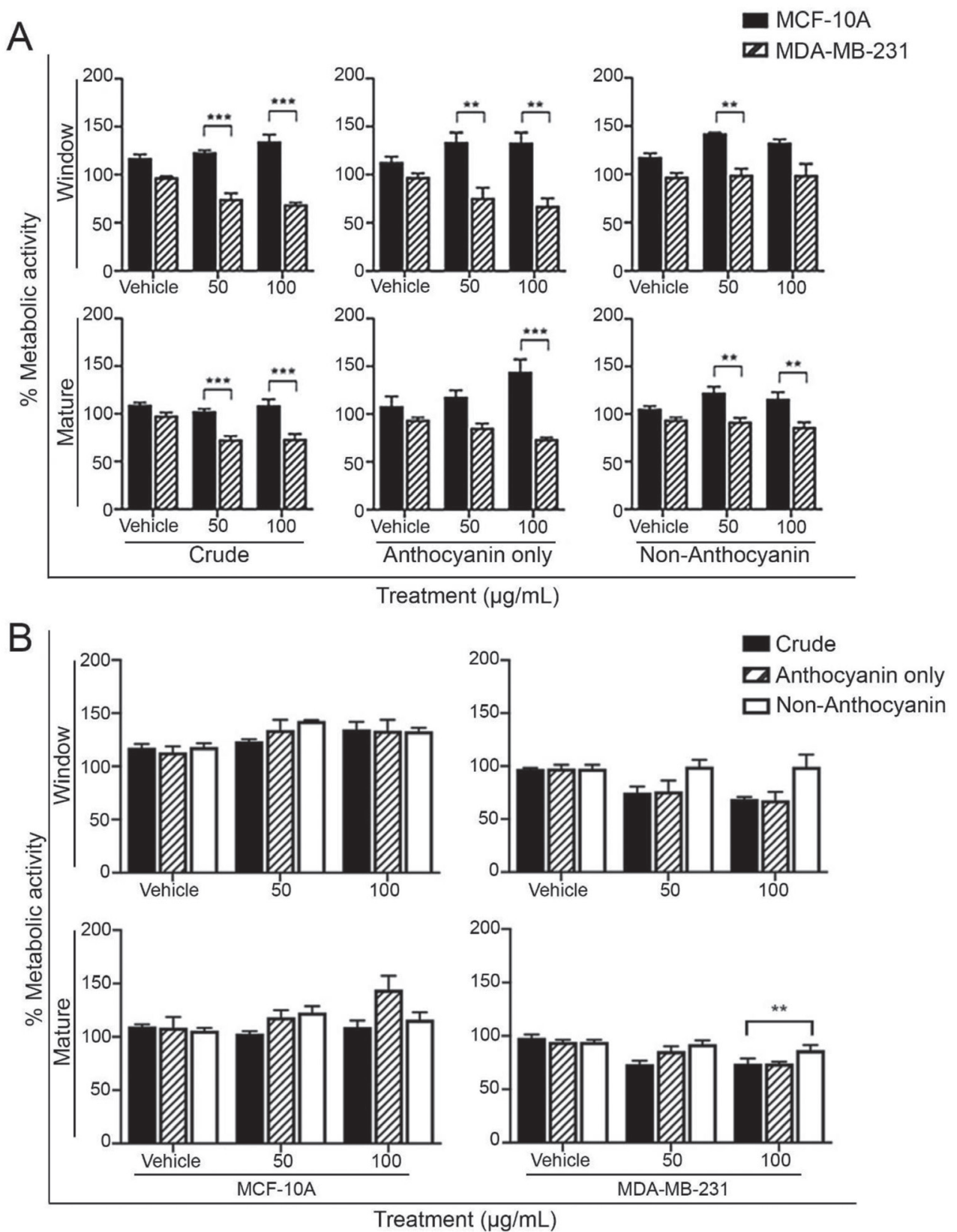

Figure 7. Inhibitory effects of crude extracts and anthocyanin and non-anthocyanin fractions of A. madagascariensis window and mature stage leaves on triple-negative breast cancer cells (MDA-MB-231) compared to the immortalized human normal mammary cells (MCF-10A). (A, B) Crude extracts, and anthocyanin and non-anthocyanin fractions were applied at 0, 50 or $100 \mu \mathrm{g} / \mathrm{mL}$ on both MDA-MB-231 and MCF-10A cells that were cultured for 48 h. (A) Normal mammary epithelial control cells (MCF-10A) were not affected by either of the extract/fraction treatments, while breast cancer cells (MDA-MB-231) showed a decrease in their metabolic activity when treated with crude extracts and anthocyanin fractions. (B) There was no significant difference among crude, anthocyanin and non-anthocyanin fractions except between breast cancer cells treated with $100 \mu \mathrm{g} / \mathrm{mL}$ of mature leaf crude anthocyanin extract and $100 \mu \mathrm{g} / \mathrm{mL}$ of mature leaf non-anthocyanin fractions. Absorbance was measured at $570 \mathrm{~nm}$ and \% metabolic activity expressed as means \pm SEM of three independent experiments. Differences among means were analysed using a one-way ANOVA and Tukey's test; $* P<0.05, * * P<0.01$,

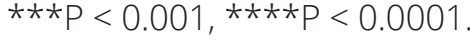


vehicle control cells and treated cells with either window or mature crude anthocyanin extracts in any of the cell lines (Figure 6). This indicates that crude anthocyanin extracts from window and mature stage leaves of A. madagascariensis do not seem to have anti-proliferative activities on ovarian (OVCAR-8 and SKOV-3) and breast (MDA-MB-231) cancer cells.

\section{No Significant Difference Between the Ability of Crude Lace Plant Anthocyanin Extracts, as well as Anthocyanin and Non-Anthocyanin Fractions, to Inhibit the Metabolic Activity of Breast Cancer Cells}

A colorimetric tetrazolium-based MTT assay was also used to detect the metabolic activity of normal mammary cells MCF-10A and TNBC MDA-MB-231 cells when treated with crude anthocyanin extracts, as well as anthocyanin and non-anthocyanin fractions from window and mature stage leaves of $A$. madagascariensis. The MTT assay results showed there was a significant difference between the control MCF-10A cells and the breast cancer MDA-MB-231 cells when treated with either 50 or $100 \mu \mathrm{g} / \mathrm{mL}$ crude anthocyanin extracts, as well as anthocyanin or non-anthocyanin fractions $(\mathrm{P}<0.05$; Figure 7A). Statistical analysis also showed that the difference between the three types of extracts tested in this study (crude, anthocyanin, and nonanthocyanin) was not significant. There were no significant differences among crude, anthocyanin and nonanthocyanin fractions except between breast cancer cells treated with $100 \mu \mathrm{g} / \mathrm{mL}$ mature leaf crude anthocyanin extract and $100 \mu \mathrm{g} / \mathrm{mL}$ mature leaf non-anthocyanin fractions (Figure 7B). The results showed that the crude extracts, as well as the anthocyanin and non-anthocyanin fractions, inhibited the metabolic activity of triplenegative breast cancer cells, but not MCF-10A cells. In addition, the three types of extracts used in this study had a similar inhibitory effect on the metabolic activity of MDA-MB-231 cells.

\section{Discussion}

This study investigated the anticancer effects of crude anthocyanin extracts from window and mature stage leaves of $A$. madagascariensis on human epithelial ovarian cancer cells, OVCAR-8 and SKOV-3, triple-negative breast cancer cells, MDA-MB-231, and immortalized human mammary cells, MCF-10A, as the control.

The MTT assay used in this study is the most common assay used to detect cell mitochondrial metabolic activity as a measure of cell growth by the conversion of tetrazolium salt MTT into formazan crystals, which can then be solubilized in DMSO [31]. The results from the MTT assays suggested that the crude anthocyanin extracts from window and mature stage leaves were selective against MDA-MB-231 triple-negative breast cancer cells, and the two human ovarian cancer cell lines OVCAR-8 and SKOV-3. Selectivity was observed because only the metabolic activity of cancer cell cultures decreased in a concentration-dependent fashion (Figure 2); no statistically significant drop in metabolic activity was recorded when the immortalized human normal mammary MCF-10A cells were treated with lace plant crude anthocyanin extracts. Contrary to previous studies with anthocyanins in which significant cytotoxicity was recorded at high concentrations such as 100 and $250 \mu \mathrm{g} / \mathrm{mL}$, lace plant anthocyanin extracts reduced cancer cell growth at low concentrations of 25 and $50 \mu \mathrm{g} / \mathrm{mL}$ (Figure 2). Diaconeasa et al. [32] reported that blueberry anthocyanin extracts showed significant cytotoxicity of about $10-15 \%$ starting at $100 \mu \mathrm{g} / \mathrm{mL}$, while blackcurrant anthocyanin extracts showed significant cytotoxicity of approximately $10-15 \%$ at $75 \mu \mathrm{g} / \mathrm{mL}$. It has been shown that the metabolic activity of ovarian cancer cells, SKOV-3 and A2780, was very high and did not significantly decrease when the cells were treated with $50 \mu \mathrm{g} / \mathrm{mL}$ anthocyanins extracts from blueberries, blackcurrant or cranberry $[32,33]$. In the present study, the metabolic activity of OVCAR-8, SKOV-3 and MDA-MB-231 cell cultures was reduced to $60 \%$ when treated with $50 \mu \mathrm{g} / \mathrm{mL}$ lace plant crude anthocyanin extracts (Figure 2). The fact that significant changes in metabolic activity were detected at low concentration of crude anthocyanin extracts suggested that a combination of polyphenolic compounds induced cell death in human ovarian cancer cells, OVCAR- 8 and SKOV-3, and the breast cancer cells, MDA-MB-231. A decline in metabolic activity was observed as the concentration of crude anthocyanin extract and treatment time increased; however, this assay only showed the overall cell population's health, and therefore did not provide insight into the type of cell death occurring in the cancer cells when treated with crude anthocyanin extracts and fractions.

Dauphinee et al. [19] showed significantly higher anthocyanin content and radical scavenging activity (ABTS assay) in window stage leaf crude anthocyanin extracts compared to the mature stage extracts. In the present study, there was generally no difference between the metabolic activity of cells treated with window and mature leaf stage crude anthocyanin extracts. If anthocyanins are the only compounds responsible for anticancer activity, a significant difference in metabolic activity would have been observed between the window and mature stage leaves. This suggests that in addition to anthocyanins, there could be other anticancer compounds present in the mature stage leaf extracts. 
Microscopic analyses, involving Crystal Violet staining, TUNEL and TEM, aid in identifying characteristics of apoptosis such as cell shrinkage, chromatin condensation, DNA laddering, membrane blebbing and formation of apoptotic bodies [34-37]. Crystal Violet staining highlighted the morphological changes that crude anthocyanin extracts from window and mature stage leaves of the lace plant caused in human ovarian cancer cells, OVCAR-8 and SKOV-3, and TNBC cells, MDA-MB-231. After $48 \mathrm{~h}$ of treatment, both 50 and $100 \mu \mathrm{g} / \mathrm{mL}$ of window and mature stage leaf anthocyanin extracts caused a reduction in number of healthy cells, increased the number of dead cells and induced morphological changes in the cytoplasm and nuclei of the remaining live cells. No significant morphological changes were observed following treatment of normal mammary epithelial MCF-10A cells suggesting that lace plant anthocyanin extracts were selective against cancer cells only (Figure 3). Similar morphological changes including a flattened appearance, as well as multiple cytoplasmic changes were also seen in the work of Devi et al. [38], who looked at the appearance of human breast cancer cells MCF-7 when treated with anthocyanin extracts of red sorghum bran. Moreover, cell morphology changes were also observed by Bunea et al. [37], who found that anthocyanin species extracted from blueberry cultivars induced apoptotic morphological characteristics like rounding up and shrinking of cells, but also membrane blebbing, detachment and formation of apoptotic bodies, all of which are hallmarks of apoptosis. Since we have observed TUNEL positive nuclei, membrane invagination, and apoptotic bodies in MDA-MB-231 TNBCs, it is reasonable to suggest that window and mature stage leaf crude anthocyanin extracts from the lace plant induce apoptosis in breast cancer cells. As previous studies showed, these are all hallmarks of apoptotic cell death [37, 39-41].

Overall, based on the morphological changes observed in this study, the lace plant crude anthocyanin extracts appeared to cause cell death in breast cancer cell lines via apoptosis. The exact mechanism of how anthocyanins cause the death of cancer cells are unknown. It is unlikely that anthocyanins interact with hormone receptors since MDA-MB-231 is a triple negative breast cancer cell line that lacks the ERa estrogen receptor [42]. Similarly, the OVCAR-8 ovarian cell line lacks ERa and does not respond to estradiol [43]. Even though the SKOV-3 ovarian cancer cell line expresses the classical estrogen receptor ER $\alpha$ [44], the absence of ERa on anthocyaninresponsive MDA-MB-231 and OVCAR-8 cells rules out anthocyanin-hormone receptor interaction. Interestingly, in anthocyanin studies, the ROS-mediated mitochondrial pathway is the most common cell death pathway being reported. Anthocyanins have the ability to transform from antioxidants to prooxidants, possibly through reactions with transition metal ions such as $\mathrm{Cu}^{2+}$ and $\mathrm{Fe}^{2+}$, which are abundant in cancer cells, to stimulate the production of ROS [45-47]). Therefore, it is possible that lace plant anthocyanins may also induce apoptosis primarily through the ROS-mediated mitochondrial pathway in triple-negative breast cancer cells. However, further investigation is needed to confirm the cell death pathway and unravel the mechanisms regulating the process.

Oregon Green-488 staining was performed to measure the ability of the lace plant crude anthocyanin extracts to inhibit the proliferation of human ovarian cancer cells OVCAR-8 and SKOV-3, and breast cancer cells MDA-MB-231. Crude anthocyanin extracts were applied to the cancer cells at sub-cytotoxic concentrations since the goal of the assay was not to kill the cancer cells, but rather to discover the concentration at which anthocyanin extracts stopped or slowed down cell division. For this reason, 25 and $50 \mu \mathrm{g} / \mathrm{mL}$ concentrations were selected, and the experiment was only performed on human ovarian and breast cancer cells, not on normal mammary MCF-10A cells. Results show that the number of cell divisions decreased when anthocyanin crude extract concentration increased from the vehicle control up to $50 \mu \mathrm{g} / \mathrm{mL}$. However, statistical analysis showed that there was no significant difference between the control treated cells and the crude anthocyanin extract treated cells for any of the cancer cell lines (Figure 6). The statistical analysis showed that crude anthocyanin extracts did not have antiproliferative activity, but we observed high variance, particularly for OVCAR-8 and MDA-MB-231 cells (Figure 6). Previous studies on anthocyanin extracts from other common fruits showed antiproliferative activities even at lower concentrations. For instance, in Loung et al. [48] the apple peel flavonoid fraction significantly reduced the number of cell divisions at 40 $\mu \mathrm{g} / \mathrm{mL}$ compared to the vehicle control. Anthocyanins are known to have antiproliferative properties due to their abilities to arrest different stages of the cell cycle by altering cell cycle regulatory proteins like cyclin A and D1, p21 as well as p27 and p53 [49]. MCF-7, HeLa, and HCT-116 cancer cells all showed a reduction in cell division when treated with anthocyanins which caused a significant increase in the percentage of cells at the sub-G0 phase [49]. Therefore, to deepen our understanding about antiproliferative activities of 
crude anthocyanin extracts from lace plant window and mature stage leaves, cell cycle analysis might need to be incorporated in our future studies. Overall, based on the current results from Oregon Green-488, the lace plant crude anthocyanin extracts do not have antiproliferative activity. The inhibitory effect of crude anthocyanin extracts from window and mature stage leaves of A. madagascariensis on breast and ovarian cancer cell metabolic activity in MTT assays was therefore likely due to cytotoxicity rather than growth inhibition.

The colorimetric MTT assay showed no significant difference among crude anthocyanin extracts, or anthocyanin and non-anthocyanin fractions in inhibiting the metabolic activity of triple-negative breast cancer cell line MDA-MB-231 (Figure 7). These results suggest that anthocyanins are not the only compounds present in the crude lace plant anthocyanin extract that contribute to the extracts' anticancer activity. Decreased metabolic activity of cells treated with anthocyanin fractions may be due to the anthocyanin species in the fraction. Lowered metabolic activity of cells treated with only the nonanthocyanin fraction supports the presence of other, yet to be identified, compounds with anticancer activities in the lace plant anthocyanin extracts.

Determining the specific identity of the compounds present in the crude anthocyanin and non-anthocyanin fractions that elicit anticancer activity is the focus of our ongoing research. Once these compounds are identified, the synergetic relationship between these compounds and anticancer properties will be studied.

\section{Conclusions}

The novel model organism Aponogeton madagascariensis was used to investigate the anticancer effects of crude anthocyanin extracts from window and mature stage leaves on human epithelial ovarian and breast cancer cells. It was found that crude extracts and extract fractions inhibited the growth of cancer cell lines, OVCAR-8, SKOV-3, MDA-MB-231, in a concentration-dependent manner, while no change was induced to the nonmalignant MCF-10A cells. Window and mature crude anthocyanin extracts induced apoptotic-like morphological changes in breast cancer cells, but no significant difference was found between the effects caused by extracts obtained from the two leaf stages. Crude anthocyanin extracts from lace plant leaves also had a slight antiproliferative activity but results from the Oregon-Green-488 assay were not statistically significant.

In summary, lace plant crude anthocyanin extracts, and their corresponding fractions, from window and mature stage leaves have anticancer activity. However, further investigation is needed to reveal what receptors and signalling pathways are involved and activated in cancer cells by the crude anthocyanin extracts and their corresponding fractions. Moreover, a combination of cell cycle and biochemical analyses might enhance our understanding of proteins that could be activated in response to the anthocyanin treatment. To deepen our understanding of the difference between crude anthocyanin extracts and fractions, more trials are needed as well as an accurate and thorough investigation of the specific species of compounds present in the lace plant window and mature stage leaves. Currently, identification of anthocyanin species and other anticancer compounds present in the lace plant is under investigation; this represents a first step towards the discovery of the identity of the compounds that are responsible for the observed anticancer activity.

\section{Authors' Contributions}

ANG: Conceived the study, participated in its design and coordination, secured funding, supervised AND's and AR's work, crystal violet imaging, TEM imaging, data interpretation, draft manuscript preparation, finalized the manuscript and completed manuscript revisions. (D) https://orcid.org/0000-0001-7241-0138

AR: Plant propagation, anthocyanin extraction, MTT assay, crystal violet staining and imaging, cell proliferation assay, statistical analysis, preparation of bar graphs, draft manuscript preparation and helped in finalizing the manuscript.

ANR: Optimization of MTT assay, Preparation of cells for TEM, TUNEL assay, and manuscript editing.

AND: Plant propagation, anthocyanin extraction, preparation of figures, graphical abstract preparation, draft manuscript preparation, manuscript editing.

WF: Trained AR for MTT assay and cell proliferation assay, contributed to statistical analysis, data interpretation, manuscript editing.

SM: Fractionation of lace plant crude anthocyanin extract, drafted the method section of fractionation of lace plant crude anthocyanin extract, data interpretation, manuscript editing

HW: Contributed to statistical analysis and manuscript editing.

(D) https://orcid.org/0000-0002-0648-2309

DWH: Supervised ANR's, AR's and WF's work, secured funding, data interpretation, manuscript editing. 


\section{Acknowledgements}

We thank Dr. Joanna Kacprzyk (University College Dublin) for critically reviewing the manuscript. We also thank Georgia Denbigh (former MSc student, Gunawardena lab, Dalhousie University) for providing anthocyanin extracts for two experiments and Mary Ann Trevors (Dalhousie Facilities) for assistance with TEM sample preparations. We thank Ginette Pitcher (Agriculture and Agri-Food Canada, Kentville NS) for preparing the anthocyanin and non-anthocyanin containing fractions of the crude lace plant anthocyanin extracts for the cancer experiments. ANG greatly acknowledges Dr. Laurent Kreplak, Associate Dean for Research, Faculty of Science, Dalhousie University for his support in initiating this interdisciplinary research collaboration.

\section{Funding}

This study was supported by the funding from the Natural Sciences and Engineering Research Council of Canada ((NSERC to DWH (grant \# 2017-05339) and ANG (grants \# 2017-04299 and 2017-507825)). DWH is a Senior Scientist of the Beatrice Hunter Cancer Research Institute and holds the Canadian Breast Cancer Foundation-Atlantic Region Endowed Chair in Breast Cancer Research, funded by the Canadian Breast Cancer Foundation/Canadian Cancer Society and the Queen Elizabeth II Foundation. ANR and WF were supported by the funding from the QEIl Foundation and the Canadian Breast Cancer Foundation. AND was supported by ANG's NSERC Discovery accelerator supplements (DAS), and a Formas mobility grant (\#201901565). AR was supported by the Sarah Lawson Research Scholarship (Dalhousie University) and ANG's discovery grant.

\section{References}

[1] Chen LY, Grimm GW, Wang QF, Renner SS. A phylogeny and biogeographic analysis for the Cape-Pondweed family Aponogetonaceae (Alismatales). Mol Phylogenet Evol. 2015;82:111-117. https://doi.org/10.1016/j.ympev. 2014.10.007

[2] Van Bruggen HW. Monograph of the genus Aponogeton (Aponogetonaceae). Schweizerbart'sche Verlagsbuchhandlung; 1985.

[3] Denbigh GL, Dauphinee AN, Fraser MS, Lacroix CR, Gunawardena AHLAN. The role of auxin in developmentally regulated programmed cell death in lace plant. Am J Bot. 2020;107:1-10. https://doi.org/10.1002/ajb2.1463

[4] Dauphinee AN, Denbigh GL, Rollini A, Fraser M, Lacroix CR, Gunawardena AHLAN. The function of autophagy in lace plant programmed cell death. Front Plant Sci. 2019;10:1198. https://doi.org/10.3389/fpls.2019.01198

[5] Rowarth NM, Dauphinee AN, Denbigh GL, Gunawardena AHLAN. Hsp70 plays a role in programmed cell death during the remodelling of leaves of the lace plant (Aponogeton madagascariensis). J Exp Bot. 2019;71: 907-918. https://doi.org/10.1093/jxb/erz447

[6] Fraser MS, Dauphinee AN, Gunawardena AHLAN. Determining the effect of calcium on cell death rate and perforation formation during leaf development in the novel model system, the lace plant (Aponogeton madagascariensis). J Microsc. 2019;278:132-144. https:// doi.org/10.1111/jmi.12859

[7] Dauphinee AN, Gunawardena AN. An overview of programmed cell death research: From canonical to emerging model species. In AN Gunawardena \& PF McCabe (Eds.), Plant programmed cell death; 2015: $1-31$.

[8] Wertman J, Lord CEN, Dauphinee AN, Gunawardena AHLAN. The pathway of cell dismantling during programmed cell death in lace plant (Aponogeton madagascariensis) leaves. BMC Plant Biol. 2012;12:115. https://doi.org/10.1186/1471-2229-12-115

[9] Gunawardena AHLAN, Navachandrabala C, Kane M, Dengler NG. Lace plant: A novel system for studying developmental programmed cell death. In JA Teixeira da Silva (Ed.), Floriculture, ornamental and plant biotechnology: Advances and topical issues; 2006;157-162. Middlesex: Global Science Books.

[10] Gunawardena AHLAN, Greenwood JS, Dengler NG. Programmed cell death remodels lace plant leaf shape during development. Plant Cell. 2004;16:60-73. https:// doi.org/10.1105/tpc.016188

[11] Chowdhury NS, Islam TB, Farjana F, Jamali S. Pharmacological values and phytochemical analysis of aquatic plant genus Aponogeton: A review. IJRIAR. 2019;3:125-141. https://www.researchgate.net/ publication/334559686_Pharmacological_Values_and_ Phytochemical_Analysis_of_Aquatic_Plant_Genus_ Aponogeton_A_Review

[12] Ali SI. Contribution to the family Aponogetonaceae from Pakistan. Pak J Bot. 2008;40:1-3. http://www.pakbs.org/ pjbot/pjhtmls/PJB.html

[13] Les D, Moody M, Jacobs S, Meerow A. Phylogeny and systematics of Aponogeton (Aponogetonaceae): The Australian species. Syst Bot. 2005;30:503-519. https:// doi.org/10.1600/0363644054782215

[14] Lim TK. Edible medicinal and non medicinal plants (Vol 9). Netherlands: Springer.

[15] Dash S, Kanungo SK, Dinda SC. Antidiabetic activity of Aponogeton natans (linn) engl. and krause- and important folklore medicine. Int J Pharm Pharm. 
2014;6:574-577. https://innovareacademics.in/journal/ ijpps/Vol6lssue1/8260.pdf

[16] Rahman MS, Alam MB, Choi YH, Yoo JC. Anticancer activity and antioxidant potential of Aponogeton undulatus against Ehrlich ascites carcinoma cells in Swiss albino mice. Oncol Lett. 2017;14:3169-3176. https://doi. org/10.3892/ol.2017.6484

[17] Islam MR, Alam MB, Tamima U, Jenny SI. Antitumor activity of Aponogeton undulatus against Ehrilich ascites carcinoma in Swiss albino mice. Asian Pac J Trop Med. 2015;8:431-437. https://doi.org/10.1016/j. apjtm.2015.05.010

[18] Jayaweera DMA. Medicinal plants (indigenous and exotic) used in Ceylon. Colombo: National Science Council of Sri Lanka.

[19] Dauphinee AN, Fletcher Jl, Denbigh GL, Lacroix CR, Gunawardena AHLAN. Remodelling of lace plant leaves: Antioxidants and ROS are key regulators of programmed cell death. Planta. 2017;246:133-147. https:// doi.org/10.1007/s00425-017-2683-y

[20] Pervaiz T, Songtao J, Faghihi F, Salman M, Fang J. Naturally occurring anthocyanin, structure, functions and biosynthetic pathway in fruit plants. Plant Physiol Biochem. 2017;5:1-9. https://doi. org/10.4172/2329-9029.1000187

[21] Malik M, Zhao C, Schoene N, Guisti MM, Moyer MP, Magnuson BA. Anthocyanin-rich extract from Aronia meloncarpa e. induces a cell cycle block in colon cancer but not normal colonic cells. Nutr Cancer. 2003;46:186196. https://doi.org/10.1207/S15327914NC4602_12

[22] He K, Li X, Chen X, Ye X, Huang J, Li P, Deng Y, Jin Q, Shi $Q$, Shu $\mathrm{H}$. Evaluation of antidiabetic potential of selected traditional Chinese medicines in STZ-induced diabetic mice. J Ethnopharmacol. 2011;137:1135-1142. https:// doi.org/10.1016/j.jep.2011.07.033

[23] Khoo HE, Azlan A, Tang ST, Lim SM. Anthocyanidins and anthocyanins: Colored pigments as food, pharmaceutical ingredients, and the potential health benefits. Food Nutr Res. 2017;61:1-21. https://doi.org/10.1080/16546 628.2017 .1361779

[24] Dai J, Gupte A, Gates L, Mumper RJ. A comprehensive study of anthocyanin-containing extracts from selected blackberry cultivars: Extraction methods, stability, anticancer properties and mechanisms. Food Chem Toxicol. 2009;47:837-847. https://doi.org/10.1016/j. fct.2009.01.016

[25] Singletary KW, Jung KJ, Giusti M. Anthocyanin-rich grape extract blocks breast cell DNA damage. J Med Food. 2007;10:244-251. https://doi.org/10.1089/jmf.2006.258

[26] Wang LS, Stoner GD. Anthocyanins and their role in cancer prevention. Cancer Lett 2008;269:281-290. https:// doi.org/10.1016/j.canlet.2008.05.020
[27] Favaro LIL, Balcao VM, Rocha LKH, Silva EC, Oliveira Jr, JM, Vila MMDC, Tubino M. Physicochemical characterization of a crude anthocyanin extract from the fruits of Jassara (Euterpe edulis Martius): Potential for food and pharmaceutical applications. J Brazil Chem Soc. 2018;29:20722088. https://doi.org/10.21577/0103-5053.20180082

[28] Kupcsik L. Estimation of cell number based on metabolic activity: The MTT reduction assay. Methods Mol Biol. 2011;740:13-19. https://doi.org/10.1007/978-1-61779108-6_3

[29] Sharma R, Ahmad G, Esteves SC, Agarwal A. Terminal deoxynucleotidyl transferase dUTP nick end labeling (TUNEL) assay using bench top flow cytometer for evaluation of sperm DNA fragmentation in fertility laboratories: Protocol, reference values, and quality control. J Assist Reprod Genet. 2016;33:291-300. https://doi. org/10.1007/s10815-015-0635-7

[30] Henkel R, Hoogendijk CF, Bouic PJD, Kruger TF. TUNEL assay and SCSA determine different aspects of sperm DNA damage. Andrologia. 2010;4:305-313. https://doi. org/10.1111/j.1439-0272.2009.01002.x

[31] Van MeerlooJ, Kaspers GJL, Cloos J. Cell sensitivity assays: The MTT assay. Methods Mol Biol. 2011;731:237-245. https://doi.org/10.1007/978-1-61779-080-5_20

[32] Diaconeasa Z, Leopold L, Rugina D, Ayvaz H, Socaciu C. Antiproliferative and antioxidant properties of anthocyanin rich extracts from blueberry and blackcurrant juice. Int J Mol Sci. 2015;16:2352-2365. https://doi. org/10.3390/ijms16022352

[33] Singh AP, Singh RK, Kim KK, Satyan KS, Nussbaum R, Torres M, Brard L, Vorsa N. Cranberry proanthocyanidins are cytotoxic to human cancer cells and sensitive platinum resistant ovarian cancer to paraplatin. Phytother Res. 2009;23:1066-1074. https://doi.org/10.1002/ptr.2667

[34] Earnshaw WC. Nuclear changes in apoptosis. Curr Opin Cell Biol. 1995;7:337-343. https://doi.org/10.1016/09550674(95)80088-3

[35] O'Brien IEW, Baguley BC, Murray BG, Morris BAM, Ferguson IB. Early stages of the apoptotic pathway in plant cells are reversible. Plant J. 1998;13:803-814. https://doi.org/10.1046/j.1365-313X.1998.00087.x

[36] Kerr JFR, Wyllie AH, Currie AR. Apoptosis: A basic biological phenomenon with wide-ranging implications in tissue kinetics. Br J Cancer. 1972;26:239-257. https://doi. org/10.1038/bjc.1972.33

[37] Bunea A, Rugina D, Sconta Z, Pop RM, Pintea A, Socaciu C, Tabaran F, Grootaert C, Struijs K, VanCamp J. Anthocyanin determination in blueberry extracts from various cultivars and their antiproliferative and apoptotic properties in B16-F10 metastatic murine melanoma cells. Phytochemistry. 2013;95:436-444. https:// doi.org/10.1016/j.phytochem.2013.06.018 
Gunawardena et al. | Journal of Natural Health Product Research, 2021, Vol. 3, Iss. 2, pp. 1-17.

[38] Devi PS, Kumar MS, Das SM. Evaluation of antiproliferative activity of red sorghum bran anthocyanin on a human breast cancer cell line (MCF-7). Int J Breast Cancer. 2011;891481. https://doi.org/10.4061/2011/891481

[39] Germain F, Fernandez E, De La Villa P. Morphological signs of apoptosis in axotomized ganglion cells of the rabbit retina. Neuroscience. 2007;144:898-910. https:// doi.org/10.1016/j.neuroscience.2006.10.039

[40] Guadamillas MC, Cerezo A, del Pozo MA. Overcoming anoikis - pathways to anchorage-independent growth in cancer. J Cell Sci. 2011;124:3189-3197. https://doi. org/10.1242/jcs.072165

[41] Igney FH, Krammer PH. Death and anti-death: Tumour resistance to apoptosis. Nat Rev Cancer. 2002;2:277-288. https://doi.org/10.1038/nrc776

[42] Flodrova D, Toporova L, Macejova D, Lastovickova M, Brtko J, Bobalova J. A comparative study of protein patterns of human estrogen receptor positive (MCF-7) and negative (MDA-MB-231) breast cancer cell lines. Gen Physiol Biophys. 2016;35:387-392. https://doi. org/10.4149/gpb_2016009

[43] Jackson KA, Oprea G, Handy J, Kimbro KS. Aberrant STYK1 expression in ovarian cancer tissues and cell lines. J Ovarian Res. 2009. https://doi.org/10.1186/17572215-2-15

[44] Chan KKL, Siu MKY, Jiang Y, Wang J, Wang Y, Leung THY. Differential expression of estrogen receptor subtypes and variants in ovarian cancer: Effects on cell invasion, proliferation and prognosis. BMC Cancer 2017;17:606. https://doi.org/10.1186/s12885-017-3601-1

[45] Sotler R, Poljšak B, Dahmane R, Jukić T, Jukić DP, Rotim C, Trebše P, Starc A. Prooxidant activities of antioxidants and their impact on health. Acta Clin Croat. 2019;58: 726-736. https://doi.org/10.20471/acc.2019.58.04.20

[46] Eghbaliferiz S, and Iranshahi M. Prooxidant activity of polyphenols, flavonoids, anthocyanins and carotenoids: updated review of mechanisms and catalyzing metals. Phytother Res. 2016;30:1379-1391. https://doi. org/10.1002/ptr.5643.

[47] Jung M, Mertens C, Tomat E, Brüne B. Iron as a central player and promising target in cancer progression. Int J Mol Sci. 2019;20:273. https://doi.org/10.3390/ ijms20020273

[48] Loung CY, Fernando W, Rupasinghe HPV, Hoskin DW. Apple peel flavonoid fraction 4 suppresses breast cancer cell growth by cytostatic and cytotoxic mechanisms. Molecules. 2019;24:3335. https://doi.org/10.3390/ molecules24183335

[49] Vishnu VR, Renjith RS, Mukherjee A, Anil SR, Skreekumar J, Jyothi AN. Comparative study on the chemical structure and in vitro antiproliferative activity of anthocyanins in purple root tubers and leaves of sweet potato (Ipomoea batatas). J Agric Food Chem. 2019;67: 2467-2475. https://doi.org/10.1021/acs.jafc.8b05473 


\section{Article Information}

Managing Editor: Kieran Cooley

Peer Reviewers: Siyaram Pandey, Chantal Matar, Luc Martin

Article Dates: Received May 05 21; Accepted Jul 19 21; Published Sep 0221

\section{Citation}

Please cite this article as follows:

Gunawardena AN, Rollini A, Rasmussen AN, Dauphinee AN, Fernando W, Mackinnon S, Wright AH, Hoskin DW. In vitro Anticancer Activity of Aponogeton madagascariensis Anthocyanin Extracts. Journal of Natural Health Product Research. 2021 Sep 02: 3(2). https://jnhpresearch.com/index.php/jnhpr/article/view/19

DOI Link: https://doi.org/10.33211/jnhpr.19

\section{Copyright}

(c) Arunika N. Gunawardena, Alice Rollini, Andrea N. Rasmussen, Adrian N. Dauphinee, Wasundara Fernando, Shawna Mackinnon, A. Harrison Wright, David W. Hoskin (2021). Published first in the Journal of Natural Health Product Research. This is an open access article distributed under the terms of the Creative Commons Attribution License (https://creativecommons.org/licenses/by/4.0/), which permits unrestricted use, distribution, and reproduction in any medium, provided the original work, first published in the Journal of Natural Health Product Research, an NHP Publications journal, is properly cited. The complete bibliographic information, a link to the original publication on https://www.jnhpresearch.com, as well as this copyright and license information must be included.

Journal of Natural Health Product Research
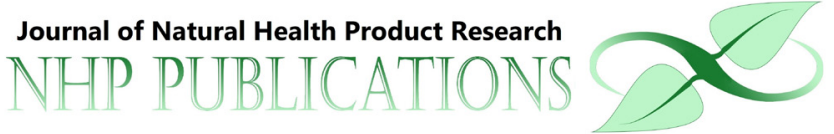

Canadàa

Does the safety, efficacy, and quality of natural health products matter to YOU?

Submit your research article to the Journal of Natural Health Product Research!

Pre-submission inquiries? Send us an email at editorial.office@jnhpresearch.com Facebook, Twitter and LinkedIn: @NHPPublications 